\title{
15 The informal economy in urban Africa
}

\section{Challenging planning theory and praxis}

\author{
Caroline Skinner and Vanessa Watson
}

This chapter starts by outlining the extent of informal work and settlements in Africa, showing that rather than being an aberration, informality is the norm. The current governance context suggests significant dissonance between city aspirations and planning systems and pervasive informality, resulting in widespread exclusionary practices. Reflecting on lessons from cases of inclusive planning, we highlight the conventional wisdoms in planning that need to be challenged. We go on to consider implications for planning practice and conclude with areas for future research.

\section{Extent of informality in urban Africa}

There are two major characteristics of African urban areas that both the literature and policy often view separately - informal work and informal settlements. What the first-ever global estimates of informal employment, compiled by the International Labour Organization (ILO) with support from WIEGO (Women in Informal Employment: Globalizing and Organizing), show (Table 15.1 ) is that most people who work in the Global South work in the informal economy.

Even in urban areas of Africa, over 80 per cent of all workers are informally employed. Table 15.2 shows the portion of total employment that is informal in a selection of African cities.

Alongside this high incidence of informal employment in Africa is the great extent of shelter, water and sanitation deficits. According to UN Habitat, the lowest levels of infrastructure provision are to be found in urban Africa. They estimate average coverage of water and sanitation at 89 and 69 per cent respectively, of electricity at 69 per cent and of paved roads at 28 per cent (UN Habitat 2012: 49). In 2016, they estimated that while one in every eight persons in the world lives in a slum, the situation is particularly acute in urban Sub-Saharan Africa - where over one in every two residents is a slum dweller (UN Habitat 2016: 57-8). This is less than the World Bank estimate that 61 per cent of urban Africans live in informal settlements (World Bank 2014). While exact estimates vary, what is clear is that slums in the region have grown in tandem with rapid urbanisation. 


\section{Caroline Skinner and Vanessa Watson}

Table 15.1 Informal employment as a percentage of total, rural and urban employment by geographic region (excluding developed countries), 2016*

\begin{tabular}{llll}
\hline Region & Total & Rural & Urban \\
\hline Asia and Pacific & 71 & 86 & 51 \\
Sub-Saharan Africa & 89 & 90 & 81 \\
- Southern Africa & 40 & 57 & 33 \\
- Rest of Sub-Saharan Africa & 92 & $92^{* *}$ & 85 \\
Latin America and the Caribbean & 54 & 69 & 48 \\
Middle East and North Africa & 68 & 74 & 60 \\
Eastern Europe and Central Asia & 37 & 47 & 29 \\
\hline
\end{tabular}

Source: Bonnet et al. (2019), Table 3.3, p. 12.

Notes

* These data are for emerging and developing countries only, not developed countries, in the regions.

** For developing countries, the estimates of informal employment in rural and urban areas are based on a smaller number of countries (with available data) than the estimates for total employment. This accounts for the same estimate for total and rural in developing countries.

Table 15.2 Informal employment as a percentage of total employment in a selection of African cities

\begin{tabular}{lll}
\hline Country & City & Percentage \\
\hline Benin & Cotonou & 83 \\
Burkina Faso & Ouagadougou & 81 \\
Côte d'Ivoire & Abidjan & 79 \\
Madagascar & Antananarivo & 64 \\
Mali & Bamako & 83 \\
Niger & Niamey & 77 \\
Senegal & Dakar & 80 \\
Togo & Lomé & 83 \\
\hline
\end{tabular}

Source: adapted from www.wiego.org/informal-economy/statistics/statistical-picture

These trends are intimately interconnected - those who work informally often live in slums, slums are not just places of reproduction but also places of work. A critical factor that needs to be taken into account in both the design and building of informal structures and their location is (largely informal) work activities.

\section{Governance context shaping livelihood possibilities}

Governance has a significant impact on informal work in urban areas, primarily through land use management and planning systems. Most countries have detailed and elaborate national planning laws which are often inherited from earlier colonial governments and have remained largely unchanged. These laws embody older and European visions of what modern cities should be like. They emphasise order, cleanliness, adherence to building and planning laws, and mono-functional neighbourhoods. They assume that informal work and dwellings 
are not present or need to be removed. In many university planning schools, students are taught to implement this kind of planning through master planning and land use zoning. More recent plans for African cities continue this modernist tradition and follow similar principles of orderliness and cleanliness. But there are some important contradictions about the way planning systems function.

The primary contradiction is that most of these cities and towns are largely unplanned - informality is everywhere. Elaborate formal planning laws have little effect on the ground. Yet this does not make life easier for those who live and work informally. The inappropriate and unimplementable formal planning systems become a political tool for politicians, officials and even informal workers and residents themselves. Time and again politicians have used planning arguments such as the need to "restore order", "modernise" and "clean up the city" to evict thousands of informal workers and informal settlement residents.

This has frequently happened where urban voters support national opposition parties. On other occasions, informal presence has been encouraged by politicians as a "vote-banking" strategy before elections. Or informal workers themselves offer political support to promote their claims to land and space. Hence cities in Africa (and elsewhere) are often driven by patron-client networks searching for exploitative rent-seeking opportunities both outside of, and through, formal government institutions and regulations. This is well documented across the continent - notable examples are Zimbabwe's 2005 “Operation Marambatsvini" (Kamete 2007a) and ongoing harassment particularly of street vendors (Rogerson 2016), Johannesburg's "Operation Clean Sweep" (Bénit-Gbaffou 2016), Blantyre's “Operation Dongosolo” (Riley 2014) as well as cases in Nigerian cities (Onodugo et al. 2016); Nairobi (Morange 2015); Accra (Steel et al. 2014); Lilongwe (Tonda and Kepe 2016) and Kampala (Young 2017).

An added dimension is the big new player in African cities: international property developers. Post the 2008 financial crisis, interest in the African property market has led to a host of urban land grabs with developers claiming they can create "world class cities" through "master planning" Dubai and Shanghai look-alike projects. Increasingly politicians support these to gain prestige and sometimes wealth. But these projects are simply new versions of urban colonial modernisation and are serving to marginalise and exclude even further those working and living informally (Watson 2014).

\section{Challenging conventional wisdoms}

Reconsidering the role of planning in relation to the informal economy and to informal settlements needs to happen conceptually as well as in practice. There are a number of conventional wisdoms in planning regarding informality which must be challenged - notions around the mono-functionality of homes and the role of public space; that informally prepared and distributed foods are a threat to consumer health and that informal workers are not contributing to the 
economy, to climate change mitigation or to urban service delivery. We consider each of these in turn.

\section{The home is a workspace for many low-income households}

The first conceptual shift needed to inform livelihood-supporting planning approaches is the acknowledgement that housing, and settlements, have an economic function. Poor households all over the world use their homes to generate income through making and/or selling products and services from these sites. Yet single-use zoning schemes and infrastructure planning, as well as many state housing policies, fail to recognise this important economic role of housing and can end up banning such activity and adding to economic costs and inefficiencies for home-based workers.

The Mahila Housing Trust's (MHT) slum upgrading work in four states of India effectively incorporates the economic function of housing, recognising that for many of the over 1.5 million members of the Self-Employed Women's Association (SEWA), their homes also function as workplaces. Obino notes that in most cases, housing improvements were linked to a desire to expand economic productivity. For home-based workers, better housing and services allowed more time at productive work, better access to water and safer storage for stocks. An electrical connection can allow better equipment such as an electric sewing machine, while a water connection quickens the production of food to be sold on the street. Studies have also found that improved infrastructure can stimulate investment in housing, but often this is dependent on loans from financial institutions (Obino 2013: 4).

\section{Informal workers should have the right to work in public spaces}

Many constitutions recognise the right to work. In Colombia, India and Mexico, court decisions have drawn on this constitutional right and affirmed the right to work on the street. Invoking these constitutional rights represents an advance on the far more prevalent view that any form of street-vending is against the law, but they do fall short of the specific position that work is a right and prohibition of street trading is a denial of that right (Meneses-Reyes and Caballero-Juárez 2014). Brown (2015) suggests that urban public space should be considered a common resource, offering open access to those attempting to secure an income. Secure tenure for livelihoods demands as much recognition as it does for housing and it is quite possible to extend civil and common law traditions in many parts of Africa to accommodate a broader definition of these rights. Brown's African case studies show that in the absence of constitutional measures, collective action by informal workers can also open up the opportunity for dialogue with the state on rights to public space.

These arguments for access to streets and public spaces for work have significant implications for urban planning. Street vendors and other informal workers as well as pedestrians, vehicles and recreational activities use public space and 
mutual accommodation needs to be found. Street vendors need secure access to public space but also have a need for basic infrastructure such as running water, electrical connections, waste disposal and toilets. For street vendors as well as informal traders located in built markets, priorities are shelter from the elements, tables to display goods and storage facilities. Where electricity is accessible, some vendors have started more lucrative and value adding trades - carpentering, sewing, catering and computer and cell phone repairs. ${ }^{1}$ For waste pickers, sorting and storage facilities can transform their work environment and enhance their productivity and earning capacity (Dias and Samson 2016).

\section{Informal food trade contributes to addressing food insecurity and thus improved health}

Planning needs to shift from the assumption that informal food preparation and vending are a health threat and should be removed, to an acknowledgement of the positive health and economic benefits of this sector if it is correctly supported and managed. Urban food security is a key concern in poorer communities, and the informal economy is an important way in which the poor gain access to food. A 2009 survey across poor areas in 11 cities in southern Africa showed a high level of reliance on informal sources for food needs, with some 70 per cent of households surveyed normally sourcing food from informal outlets (Crush and Frayne 2011: 798). Yet planning and health regulations frequently make it extremely difficult for food vendors to operate either in public spaces or in residential areas and this undermines the access of households to cheap and nutritious food. Moreover, when food vendors are subject to large-scale eviction measures, as happened in Blantyre in Malawi in 2006, then the "geography of urban poverty is reshaped" and households no longer able to access these cheaper outlets suffer worsened food insecurity (Riley 2014).

Where informal vendors or traders are operating in public spaces and markets, the municipality needs to provide services and facilities to ensure a healthy selling environment. In Warwick Junction in Durban, South Africa, this was achieved through a partnership between the vendors/traders and the municipality, along with the careful design of facilities. Water points were designed and located to allow for their multiple use for washing, vegetable cleaning, cooking and taxi-washing. Toilets were easy to maintain, and were arranged in smaller blocks distributed throughout the market. Municipal waste removal was supplemented by volunteer market cleaners and intermittent "cleaning blitzes" (Dobson and Skinner 2009: 114-17).

\section{Informal operators can contribute to climate change mitigation and improved urban services}

The contribution of the informal economy to urban sustainability is rarely recognised. It is more often regarded as a polluter of the environment, and planning, health and environmental regulations are used to remove and repress it. Yet 
informal vendors and traders often source locally and make less use of polluting plastic packaging than formal shops.

Municipal waste management schemes that integrate informal recyclers emit fewer greenhouse gases, as has been proved in Colombia (Sintana, Damgaard and Gomez 2015). In many countries, waste picker movements have negotiated with governments to secure integration into municipal recycling schemes. Peru and Brazil have both passed progressive national laws that support the integration and recognition of waste pickers and their cooperatives. In Peru, Law 29.419 of 2010 regulates the activity of waste pickers, encouraging the registration of waste pickers via incentives to form waste pickers' cooperatives (the reduction of taxes and the offer of capacity building programmes) while Brazilian law mandates the inclusion of waste picker associations into solid waste management systems (Dias 2011b). Belo Horizonte in Brazil, Bogotá in Colombia and Pune in India offer examples of successful integration of waste pickers into municipal waste management schemes.

Dias details the different approaches (2016: 379-82). In all these cases, strong cooperatives of waste pickers have advocated for the right to access waste (in the case of Bogotá, through the courts) and have secured formal agreements with local authorities. In Belo Horizonte, the council has established facilities to sort and process waste which the cooperatives manage, and are now receiving financial incentives for the services they provide. In Pune, the waste picker cooperative has been contracted by the city as an independent service provider with agreed performance indicators doing door-to-door collection and receiving user fees. The Council provides equipment, working space and technical training. In 2010, the then mayor of Bogotá, in response to a Constitutional Court ruling mandating that waste picker cooperatives had the right to bid for solid waste management contracts, created a public waste management authority to integrate and pay waste pickers for the collection, transportation and recuperation of recyclables.

\section{Implications for planning practice}

There is a significant gap between the needs of those working informally and the expertise and training of officials charged with the planning and management of informal workplaces and spaces. Planning officials rarely understand the highly specific and differentiated locational and service requirements of informal workers or where their activities fit into wider value chains. It is therefore essential that any urban intervention aimed at supporting the informal economy (whether in public space or home-based) involves extensive negotiation and participatory planning processes, as well as professionals willing and able to consider new forms of infrastructure provision and new or adapted rules to manage their use and servicing.

Key to supportive interventions is understanding economic dynamics. In Warwick Junction, Durban, South Africa, for example, understanding the specific economic dynamics within different segments of the informal economy was 
crucial. Through observation, consultation and many one-on-one discussions, it became clear that interventions to enhance the livelihoods of traditional medicine traders were different from interventions needed for bovine head cookers, which were different again from supporting waste pickers operating in the area. Gleaning these insights involved municipal staff spending much time on the streets observing how space was used; one-on-one discussions with individual traders about their suppliers and customers to document backward and forward linkages of particular trades; and carefully designed participatory processes with groups of traders using role play among other techniques (Dobson and Skinner 2009). Planners also need to understand the impact of value chains. For example, for waste pickers the price of recycled metal is set globally and determined by the needs of the big players in China and the East, and this directly affects their ability to survive economically.

Factors common to the approach in these cases are:

- individual informal workers (particularly women) and their organisations are integrally involved in the process;

- there is recognition of informal workers as knowledgeable and legitimate partners;

- planners thus function as facilitators rather than all-knowing experts.

In addition, these cases show the importance of an incremental approach to upgrading, making use of experimentation through "pilots", rather than end-state and inflexible master planning.

A central issue, however, is the necessary balance between regulation and control, on the one hand, and inclusive and supportive planning approaches, on the other. Where there are competing and conflicting claims on public space (vendors vs. pedestrians, commercial vs. social uses of space), or home-based work which negatively affects neighbours, processes need to be in place, and institutionalised, to reach consensus agreements and mediate competing claims. Such arrangements will inevitably be highly context-specific: there are no models which can work across all places. The importance of consultative approaches and collective action on the part of informal workers has been emphasised above; both allow agreements (even in conflictual situations) to be worked out and reinforced in wider forums.

One consultative process increasingly acknowledged as having potential for both informal workers and shack-dwellers is that of co-production. In this process, communities and groups organise using mapping, surveys, savings schemes and learning exchanges to facilitate their empowerment, and then engage in partnerships with government on upgrade processes. With both knowledge and funding supporting them, communities are far better placed to secure appropriate planning interventions. While co-production often focuses on informal settlement upgrading, there are also economic benefits to be negotiated. For example, a co-production process in Malawi on water access involved the state and communities as well as informal water vendors. The co-production 
arrangement improved water access through increased communal water-kiosks, though the functioning of the entire water supply system was not without problems (Adams and Boateng 2018).

\section{Future research priorities}

What is being suggested is a fundamentally different approach to planning practice - bottom-up, incremental, flexible, economically conversant and acutely aware of, and informed by, the specific context and power dynamics. This calls for a new cohort of planning practitioners who are willing (and brave enough) to try out new approaches as a few experimenters have already done in the cases we have highlighted. Importantly, those working and living informally have a nuanced understanding of their context, challenging the very notion of "who is a planner".

In terms of research priorities to support this change, we prioritise detailed case study work in what are often regarded as peripheral, informal areas in the "ordinary" cities and towns. Duminy et al. (2014: 1) support "careful empirical analysis of what actually exists, and critical reflection on how it has come to be that way". Highly contextualised knowledge of the interests, power relations and actual daily practices underpinning inclusionary planning processes is the route to transforming them.

These case studies should feed into three important processes. First is changing planning laws. Berrisford and McAuslan (2017) argue that the future of African cities must be shaped by laws that address the lived experience of households and firms. They suggest this requires taking some Western-style laws and some locally emerging ones, identifying the aspects of each that are effective, and knitting these together into a legal model that works. This in turn requires deep and context-specific research.

Second is the training of a new cohort of urban planners as is occurring through the Indian Institute of Human Settlements and the African Association of Planning Schools Model Master's planning curriculum. Both are suggesting using case studies in teaching in combination with experiential learning with communities and their support NGOs, and developing good cases is an important research task (Watson and Odendaal 2013).

Third is the call within planning and urban studies to develop theory "from the South". This group of scholars (the Comaroffs, Roy, Simone, Watson, Yiftachel among others) as Bhan explains, seek to "unsettle the meta-narratives of urban theory told from the great cities - New York, Chicago, London, Paris and locate them in place and time" particularly from places that have so far been considered "peripheral" (Bhan 2016: 12).

A final addition is the need for cross-disciplinary work on informality. Empirical and theoretical work on the informal economy has largely been located in development studies and economics. There is insufficient engagement with the urban planning field and a tendency to be space-blind in terms of policy development. The need for planners to understand the economic informants of these 
The informal economy in urban Africa 131

activities suggests that urban spatial planners would do well to engage with development studies debates and vice versa.

\section{Note}

1 See, for example, in inner-city Durban (Dobson and Skinner 2009: 104). 